\title{
Germination inhibits the growth of new roots and seedlings in Eugenia uniflora and Eugenia brasiliensis ${ }^{1}$
}

\author{
Talita Silveira Amador², Claudio José Barbedo ${ }^{2 *}$
}

\begin{abstract}
Seeds of Eugenia species can produce new roots and whole plants even when much of its reserves is removed. However, new roots and seedlings rarely are formed spontaneously, and after cutting, each seed fragment usually produces only one new seedling, suggesting some control of the formation of several seedlings. It is possible, therefore, that germination leads to the production of inhibitory substances avoiding the development of new embryonic tissues. In the present work we have analyzed the potential of germinating seeds of Eugenia uniflora and Eugenia brasiliensis to inhibit new roots and seedling growth. Seeds were germinated after totally or partially fractionated. This last one was also totally fractionated after the development of a seedling, and the halves were also germinated. The results showed that the germination of the E. uniflora and E. brasiliensis seeds have inhibited the formation of new roots and seedlings.
\end{abstract}

Index terms: Myrtaceae, cutting seeds, recalcitrant seeds.

\section{Potencial de inibição da formação de raízes e plântulas em sementes germinantes de pitangueira (Eugenia uniflora) e grumixameira (E. brasiliensis)}

\begin{abstract}
RESUMO - Sementes de espécies de Eugenia têm potencial para gerar novas raízes e até plantas inteiras mesmo após a remoção de grande parte de suas reservas. Contudo, a formação de novas raízes e plântulas raramente ocorre de forma espontânea e, quando as sementes são fracionadas, cada fragmento normalmente produz apenas uma nova plântula, sugerindo algum autocontrole na formação de várias plântulas. É possível, portanto, que uma vez iniciada a germinação, a semente produza substâncias inibitórias à diferenciação de novos tecidos embrionários. No presente trabalho analisou-se, em sementes de Eugenia uniflora e Eugenia brasiliensis, o potencial de inibição do crescimento de raízes e plântulas a partir do início da primeira germinação. Sementes dessas espécies foram submetidas a fracionamento total ou parcial (fissura) e colocadas para germinar. Após a germinação das fissuradas, em uma parte das mesmas o fracionamento foi completado, separando-se as metades, que foram também colocadas para germinar. Os resultados mostraram que a germinação de sementes de E. uniflora e E. brasiliensis inicia processos de inibição da regeneração de novas raízes e plântulas na semente.
\end{abstract}

Termos para indexação: Myrtaceae, fracionamento de sementes, semente recalcitrante.

\section{Introduction}

Eugenia (Myrtaceae) comprises some native species in Brazil already domesticated and of great economic importance, such as Eugenia brasiliensis Lam. (grumixama), E. involucrata DC. (cereja do Rio Grande), E. pyriformis Camb. (uvaia) and $E$. uniflora L. (pitanga). They are species that produce fleshy fruits that are suitable for fresh consumption or for industrialization and usually have few seeds (Delgado and Barbedo, 2007; Amador and Barbedo, 2011). These show a recalcitrant behavior, with different levels of tolerance to desiccation (Delgado and Barbedo, 2007; Delgado and Barbedo, 2012).
Eugenia species seeds have the potential to generate new roots and even whole plants, even after the removal of much of their reserves (Silva et al., 2003; Prataviera et al., 2015), which is rare in nature. This feature can be used technologically to increase the potential of plantlet production. Also, there is obvious interest in understanding the factors involved in this regenerative capacity that allows the formation of new seedlings when fractionated; Eugenia embryo anatomy, for example, has been studied (Justo et al., 2007; Delgado et al., 2010). Interestingly, however, the formation of new roots and seedlings rarely occurs spontaneously: some kind of injury apparently is necessary for them to be formed (Silva et al., 2005; Amador and Barbedo, 2011).

${ }^{1}$ Submitted on 06/07/2015. Accepted for publication on 08/05/2015.

${ }^{2}$ Instituto de Botânica, Núcleo de Pesquisa em Sementes, Caixa Postal, 68041, 04301-012 - São Paulo, SP, Brasil.

*Corresponding author $<$ claudio.barbedo@pesquisador.cnpq.br> 
Despite the existence of polyembryony in species of the Myrtaceae family (Landrum and Kawasaki, 1997), the Eugenia embryos have been described as monoembryonic, which appear as globular structures, wherein the difference between the cotyledon and the radicle hypocotyl axis is visible only microscopically (Gurgel and Soubihe Sobrinho, 1951; Salomão and Allem, 2001; Justo et al., 2007; Delgado et al., 2010). However, since the development of new tissues depend on the fractionation, it is possible that injuries in seeds can start a process of inducing the formation of new roots and seedlings, or can block self-inhibition of these formations in germinating seeds. This is because it has been noticed that seeds that are fractionated can generate new seedlings, but rarely more than one new formation in each fragment, suggesting some self-control in the formation of several seedlings. Rizzini (1970) has found that E. dysenterica DC. seeds have substances that inhibit germination and that this inhibitory potential is increased when the embryo begins to germinate. Delgado and Barbedo (2011) have also found an inhibitor effect of germination on germinating seed extracts of $E$. uniflora when applied to lettuce and bean seeds. Thus, the study of inhibitors of germination can help elucidate the hypothesis of self-inhibition, as seen in coffee seeds (Pereira et al., 2002).

In studies of organogenesis, the rate of formation and the development of somatic or zygotic embryos are strongly influenced by the chemical composition of the environment. The balance among sugars, amino acids and growth regulators, for example, has shown effects that are sometimes inducers, sometimes inhibitors of the formation of new embryos (Deo et al., 2010; Kanwar et al., 2010; Karami and Saidi, 2010; Swamy et al., 2010). Thus, in Eugenia seeds, the beginning of the formation of roots or shoots could change the balance of those compounds, which makes an unfavorable medium for differentiation of new seedlings. Seeds of E. stipitata ssp. sororia, which also have the ability to regenerate embryos after fractionation, had seedling development from the seed area opposite to the damaged one, where apparently was the meristematic zone (Anjos and Ferraz, 1999). However, in the seed complementary fraction, seedlings were formed on the cut surface, which shows some polarity in mobilizing hormones. This may also be related to the fact that only after spliting the halves a second seedling can be regenerated, as shown in seeds of E. pyriformis (Amador and Barbedo, 2011). It is possible, therefore, that once initiated the germination, the seed produce substances that are inhibitory to the differentiation of new embryonic tissues by the migration of such substances from the germinating area to the others. Thus, a seed fraction could only begin to develop new roots and seedlings after being completely separated from the other tissues or at least sufficiently spaced from the growth area of an existing seedling. However, there is still little information allowing to verify the occurrence of this inhibition in Eugenia species. In the present work, in seeds of Eugenia uniflora and Eugenia brasiliensis, the potential of inhibiting the growth of roots and seedlings from the beginning of the first germination was analyzed.

\section{Material and Methods}

Fruits of E. uniflora and E. brasiliensis of two stages of ripening in each species, identified by the characteristic color of each species in the dispersion (referred to as unripe and ripe) were collected at Institute of Botany, in the Brazilian city of São Paulo, SP (23 $38^{\prime}$ S and $\left.46^{\circ} 37^{\prime} \mathrm{W}\right)$ and taken to the Laboratory of the Seed Research. The seeds were manually extracted from the fruit in sieves with running water and the fruit pulp residues were removed. After washing, the seeds remained at rest on germination paper to remove the residual surface water and were stored until the beginning of the experiments in a cold chamber at $7^{\circ} \mathrm{C}$ (Kohama et al., 2006), not exceeding 15 days.

Then the seeds of both maturity stages in both species were classified by size, according to their larger diameter, as small $(7.0 \pm 1.0 \mathrm{~mm}$ in E. uniflora and $6.5 \pm 0.5 \mathrm{~mm}$ in E. brasiliensis) and large $(9.8 \pm 0.2 \mathrm{~mm}$ in E. uniflora and $13.0 \pm 1.0 \mathrm{~mm}$ in E. brasiliensis) and evaluated for water content (expressed as a percentage, on a wet basis) by the method of oven at $103{ }^{\circ} \mathrm{C}$ for 17 hours (ISTA, 2015) with three replications of five seeds each. Samples of seeds of each size and each maturity stage were submitted to germination test in a growth chamber at $25 \pm 1{ }^{\circ} \mathrm{C}$ and $95 \pm 5 \%$ relative humidity, with continuous light provided by four fluorescent lamps of $40 \mathrm{~W}$ each. The seeds were placed on paper roll for germination, pre-moistened with tap water (Brasil, 2009), in eight replications of ten seeds each. The number of roots and seedlings produced was registered every five days, until no longer issuing new roots or epicotyls for 30 consecutive days. The protrusion of the primary root with at least $1.0 \mathrm{~cm}$ was used for the calculation of germinative seeds and the production of normal seedlings for calculating germination.

The remainder of the seeds, still separated by species, degree of maturity and size, was divided into two subgroups, one of which was placed to germinate in plastic trays with fine-grained vermiculite, and irrigated with water whenever necessary. The seeds were removed from the substrate as the roots reached $1 \mathrm{~cm}$ in length, and then stored in chambers at $7{ }^{\circ} \mathrm{C}$ within perforated polyethylene bags to obtain the number required for the experiments. The seeds of this subgroup were called pregerminated seeds (PGS), while the others were called non- 
germinated seeds (NGS).

Seeds of each subgroup of each size and each maturity stage were submitted to three treatments of incision (with a scalpel): control (kept whole), complete or partial lengthwise incision. In the NGS, the incision passed from the hilum center and in the PGS the incision was made so that one side remained with all the protruding root. In the full incision, hereinafter referred to as fractionation, two fractions were obtained and placed to germinate side by side. In PGS, the fraction containing the root was named fraction $\mathrm{R}$, and its opposite, fraction S. In the NGS, the name was arbitrary. In the partial incision, hereinafter called crack, it was held until about two-thirds of the largest diameter of the seeds, and the halves were kept linked to each other.

The cracked seeds that showed at the end of the germination tests only one primary root without noticeable development of new roots were divided into two groups. In the first group, the incision was completed until the halves were separated. The half containing the root was discarded and its complementary one was placed to germinate, and its origin control was kept and the production of roots and seedlings in the isolated fractions was assessed again. In the second group, the seeds were kept in moist vermiculite to check for possible new germinations.

A completely randomized design, in a $2 \times 2 \times 3$ factorial arrangement (PGS or NGS versus seed size versus type of incision) for each species and each maturity stage was used. The data were submitted to analysis of variance, and means were compared by Tukey test at $5 \%$ probability, by Sisvar software.

\section{Results and Discussion}

The differences in the water contents of E. uniflora seeds were higher in seeds of different sizes than in the seeds of fruit with different ripening (Table 1). Throughout ripening, seed water content tends to decrease as the dry mass is accumulated (Barbedo et al., 2013; Marcos-Filho, 2015). Therefore, the results suggest that the separation of $E$. uniflora seeds by fruit maturity degree was not efficient, in this work, in producing seeds with different maturity stages, which has already been verified in other species, according to Barbedo et al. (2013). Thus, ripe fruit seeds were not necessarily riper than those of unripe fruit. Large seeds of unripe fruits may, for example, be in a more advanced degree of ripening than the small seeds of ripe fruits, because these have shown higher water content than those (Table 1). As for the E. brasiliensis seeds used in the study, apparently they have had greater ripening synchronization with the fruits, because all unripe ones have shown higher water content than the ripe ones.

Table 1. Water content (\%) of seeds of Eugenia uniflora and E. brasiliensis obtained in two stages of fruit ripening and separated by size in small or large.

\begin{tabular}{lccc}
\hline \multirow{2}{*}{ Species } & Ripening & \multicolumn{2}{c}{ Size of seeds } \\
\cline { 3 - 4 } & of the fruit & Small & Large \\
\hline \multirow{2}{*}{ E. uniflora } & Unripe & 57.5 & 52.7 \\
& Ripe & 57.2 & 52.2 \\
E. brasiliensis & Unripe & 52.7 & 50.2 \\
& Ripe & 47.5 & 47.0 \\
\hline
\end{tabular}

In E. uniflora seeds, it was also found that while the values of germinative (whole) seeds have not shown difference among seeds of different sizes (Table 2, production of whole seed roots), the largest ones, of ripe fruits, have shown higher values of germination than the smaller ones (Table 2, production of shoots in non-germinated seeds). The values of germinative seeds and whole seed germination of E. brasiliensis, in turn, have demonstrated that the ones of ripe fruit apparently had already started a process of deterioration, as they were generally lower than those of unripe fruit (Table 3).

Seeds subjected to fractionation (Tables 2 and $3-$ fractionated) have shown again the potential of the species of the genus Eugenia to form roots and seedlings, even when half of the reserve tissue is removed from these seeds (Silva et al., 2003; Amador and Barbedo, 2011), and even when still unripe (Teixeira and Barbedo, 2012).

Another important aspect is that the cracked small E. uniflora non-germinated ripe seed showed higher germination rates than the whole ones (Table 2). This suggests that the crack has induced shoot formation in seeds that would only emit the primary root when not injured. According to Amador and Barbedo (2011), in E. pyriformis seeds it was evident that the formation of new roots and seedlings is ruled by the balance among the promoters of this formation, resulting from the cutting injury, and inhibitors, resulting from the formation of the first root or shoot. It is possible, therefore, that in the E. uniflora the fractionation injury also induces the differentiation of tissues that will produce roots and seedlings. The production of roots on E. brasiliensis PGS was lower in some treatments (especially in small seeds) than the production on NGS (Table 3). One possible explanation for this result would be that the initial root development may have caused a very low efficiency to regenerate a new root, which reinforces the idea of a process of self-inhibition of these seeds, when starting the germination (Silva et al., 2005; Amador and Barbedo, 2011). 
Table 2. Production of roots and seedlings (\% relative to the initial number of seeds) per seed or fractions of Eugenia uniflora seeds, of small and large seeds, derived from ripe or unripe fruits, with no visible germination at the time of the incision (non-germinated) or after the protrusion of least $1 \mathrm{~cm}$ of root (pre-germinated), subjected to fractionation (total separation of the seed in two halves) or cracks (cut in half to $2 / 3$ of the seed diameter without complete separation). Values represent the sum of fractions $\mathrm{R}$ and $\mathrm{S}$.

\begin{tabular}{|c|c|c|c|c|}
\hline Type of & \multicolumn{2}{|c|}{ Ripe fruit } & \multicolumn{2}{|c|}{ Unripe fruit } \\
\hline Incision & Large & Small & Large & Small \\
\hline & \multicolumn{4}{|c|}{ Production of roots } \\
\hline Whole & $98 \mathrm{bA}^{*}$ & $95 \mathrm{aA}$ & $98 \mathrm{bA}$ & $99 \mathrm{aA}$ \\
\hline Fractionated & $125 \mathrm{aA}$ & $105 \mathrm{aB}$ & $133 \mathrm{aA}$ & $104 \mathrm{aB}$ \\
\hline Cracked & $98 \mathrm{bA}$ & $103 \mathrm{aA}$ & $102 \mathrm{bA}$ & $99 \mathrm{aA}$ \\
\hline \multirow[t]{3}{*}{ C.V. $(\%)$} & \multicolumn{4}{|c|}{12.64} \\
\hline & \multicolumn{2}{|c|}{ Pre-germinated } & \multicolumn{2}{|c|}{ Non-germinated } \\
\hline & Large & Small & Large & Small \\
\hline & \multicolumn{4}{|c|}{ Production of shoots - seeds of ripe fruit } \\
\hline Whole & $95 \mathrm{aA} a$ & $95 \mathrm{aA} a$ & $89 \mathrm{aA} a$ & $62 \mathrm{bB} b$ \\
\hline Fractionated & $95 \mathrm{aA} a$ & $91 \mathrm{aA} a$ & $58 \mathrm{bA} b$ & $59 \mathrm{bA} b$ \\
\hline \multirow[t]{2}{*}{ Cracked } & $100 \mathrm{aA} a$ & $100 \mathrm{aA} a$ & $92 \mathrm{aA} a$ & $92 \mathrm{aA} a$ \\
\hline & \multicolumn{4}{|c|}{ Production of shoots - seeds of unripe fruit } \\
\hline Whole & $90 \mathrm{aA} a$ & $64 \mathrm{aB} b$ & $96 \mathrm{aA} a$ & $92 \mathrm{aA} a$ \\
\hline Fractionated & $64 \mathrm{bA} b$ & $45 \mathrm{bB} b$ & $98 \mathrm{aA} a$ & $71 \mathrm{bB} a$ \\
\hline Cracked & $91 \mathrm{aA} a$ & $64 \mathrm{aB} a$ & $98 \mathrm{aA} a$ & $64 \mathrm{bB} a$ \\
\hline C.V. $(\%)$ & \multicolumn{4}{|c|}{14.91} \\
\hline
\end{tabular}

*Means followed by the same letter (lowercase in columns, uppercase in the row and italic comparing pre-germinated with non-germinated) do not differ by Tukey test, at $5 \%$.

Table 3. Production of roots and seedlings (\% relative to the initial number of seeds) per seed or fractions of Eugenia brasiliensis seeds, of small and large seeds, derived from ripe or unripe fruits, with no visible germination at the time of the incision (non-germinated) or after the protrusion of least $1 \mathrm{~cm}$ of root (pre-germinated), subjected to fractionation (total separation of the seed in two halves) or cracks (cut in half to $2 / 3$ of the seed diameter without complete separation). Values represent the sum of fractions R and S.

\begin{tabular}{|c|c|c|c|c|}
\hline \multirow{2}{*}{$\begin{array}{l}\text { Type of } \\
\text { Incision }\end{array}$} & \multicolumn{2}{|c|}{ Pre-germinated } & \multicolumn{2}{|c|}{ Non-germinated } \\
\hline & Large & Small & Large & Small \\
\hline & \multicolumn{4}{|c|}{ Production of roots - seeds of ripe fruit } \\
\hline Whole & $100 \mathrm{bA} a^{*}$ & $100 \mathrm{aA} a$ & $88 \mathrm{abA} a$ & $76 \mathrm{aA} b$ \\
\hline Fractionated & $130 \mathrm{aA} a$ & $100 \mathrm{bB} a$ & $104 \mathrm{aA} b$ & $81 \mathrm{aB} b^{* *}$ \\
\hline \multirow[t]{2}{*}{ Cracked } & $100 \mathrm{bA} a$ & $100 \mathrm{aA} a$ & $71 \mathrm{bA} b^{* *}$ & $44 \mathrm{bB} b^{* *}$ \\
\hline & \multicolumn{4}{|c|}{ Production of roots - seeds of unripe fruit } \\
\hline Whole & $100 \mathrm{aA} a$ & $100 \mathrm{aA} a$ & $100 \mathrm{aA} a$ & $92 \mathrm{aA} a$ \\
\hline Fractionated & $100 \mathrm{aA} a$ & $111 \mathrm{aA} a$ & $112 \mathrm{aA} a$ & $51 \mathrm{bB} b$ \\
\hline Cracked & $100 \mathrm{aA} a$ & $100 \mathrm{aA} a$ & $101 \mathrm{aA} a$ & $60 \mathrm{bB} b$ \\
\hline \multirow[t]{2}{*}{ C.V. $(\%)$} & \multicolumn{4}{|c|}{18.74} \\
\hline & \multicolumn{4}{|c|}{ Production of shoots - seeds of ripe fruit } \\
\hline Whole & $91 \mathrm{aA} a$ & $60 \mathrm{bB} a$ & $71 \mathrm{aA} a$ & $54 \mathrm{aB} a$ \\
\hline Fractionated & $74 \mathrm{bB} a$ & $92 \mathrm{aA} a$ & $51 \mathrm{bA} a$ & $42 \mathrm{bA} b$ \\
\hline \multirow[t]{2}{*}{ Cracked } & $100 \mathrm{aA} a$ & $100 \mathrm{aA} a$ & $40 \mathrm{bA} b$ & $30 \mathrm{cA} b$ \\
\hline & \multicolumn{4}{|c|}{ Production of shoots - seeds of unripe fruit } \\
\hline Whole & $69 \mathrm{aB} a$ & $89 \mathrm{aA} a$ & $90 \mathrm{aA} a$ & $74 \mathrm{aB} a$ \\
\hline Fractionated & $36 \mathrm{bA} b$ & $31 \mathrm{cA} a$ & $78 \mathrm{bA} a$ & $14 \mathrm{bB} a$ \\
\hline Cracked & $71 \mathrm{aA} a$ & $66 \mathrm{bA} a$ & $80 \mathrm{abA} a$ & $24 \mathrm{bB} b$ \\
\hline C.V. (\%) & & & & \\
\hline
\end{tabular}

*Means followed by the same letter (lowercase in columns, uppercase in the row and italic comparing pre-germinated with non-germinated) do not differ by Tukey test, at $5 \%$.** They also produced roots in fraction $\mathrm{S}$.

Journal of Seed Science, v.37, n.3, p.241-247, 2015 
Germination of cracked seeds allowed the identification of seven different categories of post-crack germination, similar to that described for E. pyriformis seeds by Amador and Barbedo (2011), being shown in Figure 1A: in category I, one root or seedling are formed in one of the seed halves that was separated by the crack, which began in the area adjacent to the crack, and another root or seedling are formed in the other half; in category II, only one root or seedling are formed in the area diametrically opposed to the crack, which began in the area adjacent to the crack; in category III, only one root or seedling are formed in one of the halves, which began distant from the crack; in category IV, one root or seedling are formed in one of the halves, which began in an area distant from the crack and a root or seedling are formed in the other half, which began in the cracked surface; in category $\mathrm{V}$, one root or seedling are formed in one of the halves, which began in the area adjacent to the crack; in category VI, one root or seedling are formed in the area opposed to the crack, both initiated in the area adjacent to the crack; in category VII, two roots or seedlings are formed in one of the halves, which began in the area adjacent to the crack.
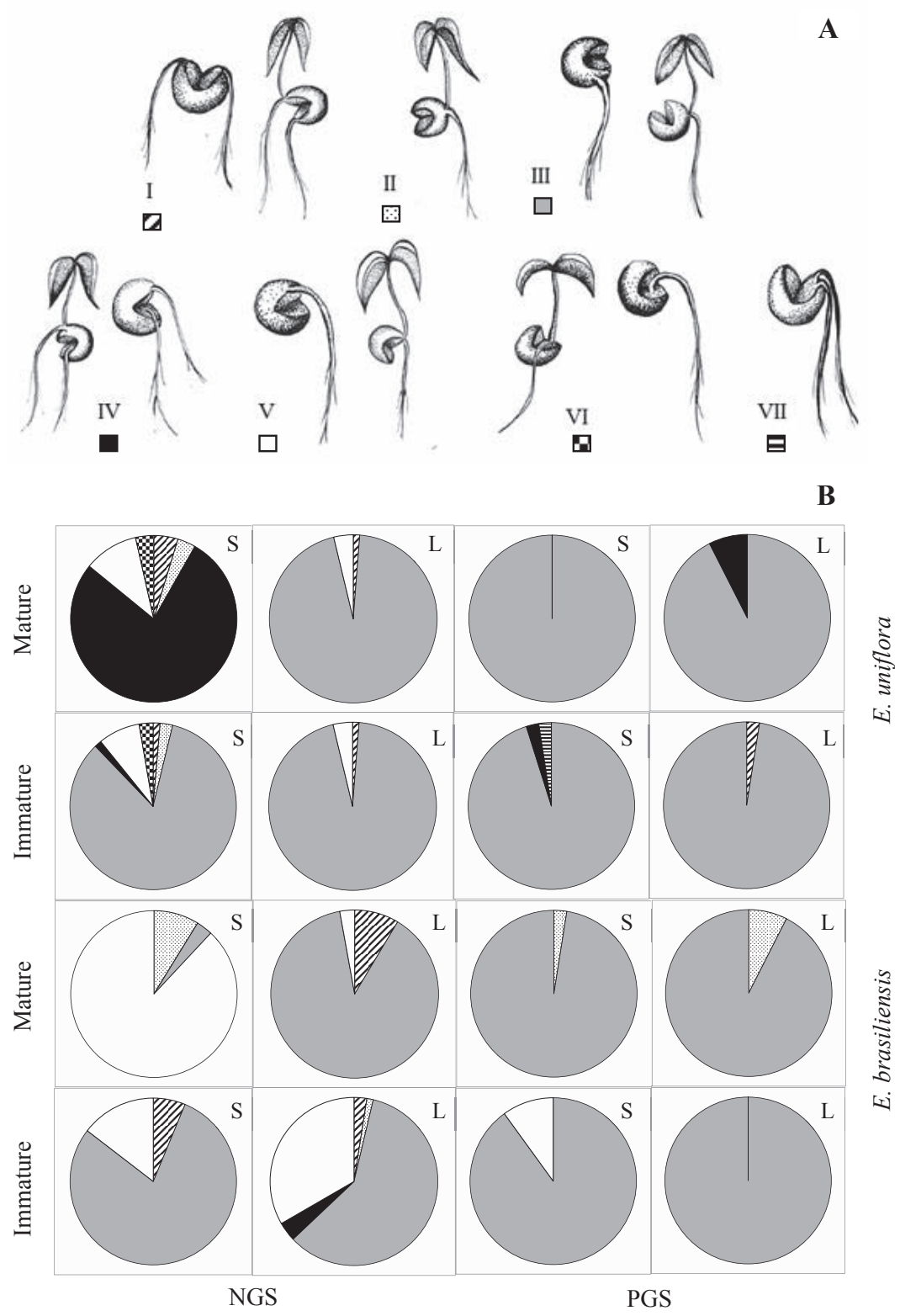

Figure 1. Models of incisions made in Eugenia uniflora and Eugenia brasiliensis seeds with their germination categories (A) and frequency distribution of the models (B) in seeds produced by unripe and ripe fruit of small (S) and large (L) sizes and in cracked seeds before (NGS) or after (PGS) germination has begun. 
It was evident that category III, i.e., formation of root or seedling in an area distant from the crack, was predominant. In 13 of 16 treatments, category III represented more than $75 \%$ of all other categories (Figure 1B). Exception is for NGS of E. uniflora ripe fruit in which category IV (forming a second root or seedling) was predominant, and E. brasiliensis, in which category $\mathrm{V}$ (in which root or seedling are formed in the area adjacent to the crack) was predominant. In unripe $E$. brasiliensis NGS, the frequency of category $\mathrm{V}$ was also high, but did not reach $50 \%$. In these last two, however, there is also the formation of only one root or seedling and, therefore, only in E. uniflora ripe fruit NGS the predominant category involved the formation of a second root or seedling. Interestingly, they are the same seeds in which the crack has induced the formation of seedlings in seeds that would form only root (Table 2), as discussed above. It is also in this category that the formation of the second root or seedling occurs in an area that is distant from the formation of the first root or seedling. This fact was also observed in E. pyriformis seeds by Amador and Barbedo (2011), who attributed the second germination to the fact that the first one occurred in a remote area, i.e., there would not be enough time for the migration of potential inhibitory substances from the first to the second germination area. Adding to the fact that in these seeds the crack may have accelerated the process of generating new seedlings, there were more favorable conditions for the factors stimulating new germination to outweigh the inhibitors, as was also discussed by Amador and Barbedo (2011).

When the fractioning of the cracked seeds of category III, which was predominant, was performed, i.e., when the crack was completed until the halves were completely separated, the fractions opposite to the fractions with root protrusion formed a new root in $28 \%$ to $75 \%$ (Table 4 ). The cracked seeds, of this same category, which were not fractionated, have never produced seedling or root in the other half. The lowest values were seen in NGS of small E. uniflora seeds, i.e., the ones with higher water content which, as noted above, were probably the unripest when harvested. It is therefore possible that the remaining reserves were not sufficient for the second germination, since most of them could have been consumed in the first germination. However, as new roots or seedlings were formed in all treatments, it is evident again that there are processes for inhibiting the development of new roots, promoted by the development of a root or seedling in the same seed, as observed in seeds of E. pyriformis by Amador and Barbedo (2011). These authors have considered that the production of inhibitory compounds should be continuous, cumulative and coming from the area in which there is seedling growth.
Table 4. Percentage of germinating fractions of seeds of $E$. uniflora and E. brasiliensis, ripe or unripe, large (L) or small (S), and pre-germinated (PGS) or nongerminated (NGS), previously cracked, which, when separated, initiated the formation of new roots.

\begin{tabular}{|c|c|c|c|c|c|c|c|c|}
\hline & \multicolumn{4}{|c|}{ E. brasiliensis } & \multicolumn{4}{|c|}{ E. uniflora } \\
\hline & \multicolumn{2}{|c|}{ Mature } & \multicolumn{2}{|c|}{ Immature } & \multicolumn{2}{|c|}{ Mature } & \multicolumn{2}{|c|}{ Immature } \\
\hline & $\mathrm{S}$ & $\mathrm{L}$ & $\mathrm{S}$ & $\mathrm{L}$ & $\mathrm{S}$ & $\mathrm{L}$ & $\mathrm{S}$ & $\mathrm{L}$ \\
\hline PGS & 55 & 65 & 52 & 50 & 75 & 58 & 55 & 68 \\
\hline NGS & 38 & 58 & 28 & 58 & 42 & 55 & 50 & 42 \\
\hline
\end{tabular}

\section{Conclusions}

Seed germination of Eugenia uniflora and Eugenia brasiliensis starts the inhibition of the formation of new roots or seedlings in the seed and seed incision can block the action of these inhibitors.

\section{Acknowledgments}

The authors thank Coordenação de Aperfeiçoamento de Pessoal de Nível Superior - CAPES (Coordination of Improvement of Higher Education Personnel) for the doctorate scholarship granted to the first author and Conselho Nacional de Desenvolvimento Científico and Tecnológico - CNPq (National Counsel of Technological and Scientific Development) for the Productivity in Research scholarship granted to the second author.

\section{References}

AMADOR, T.S.; BARBEDO, C.J. Potencial de inibição da regeneração de raízes e plântulas em sementes germinantes de Eugenia pyriformis. Pesquisa Agropecuária Brasileira, v.46, p.814-821, 2011. http://dx.doi.org/10.1590/ S0100-204X2011000800005

ANJOS, A.M.G.; FERRAZ, I.D.K. Morfologia, germinação e teor de água das sementes de araçá-boi (Eugenia stipitata ssp. sororia). Acta Amazonica, v.29, p.337-348, 1999

BARBEDO, C.J.; CENTENO, D.C.; FIGUEIREDO-RIBEIRO, R.C.L. Do recalcitrant seeds really exist? Hoehnea, v.40, p.583-595, 2013. http://dx.doi. org/10.1590/S2236-89062013000400001

BRASIL. Ministério da Agricultura, Pecuária e Abastecimento. Regras para análise de sementes. Ministério da Agricultura, Pecuária e Abastecimento. Secretaria de Defesa Agropecuária. Brasília: MAPA/ACS, 2009. 395p. http:// www.agricultura.gov.br/arq_editor/file/2946_regras_analise_sementes.pdf

DELGADO, L.F.; BARBEDO, C.J. Tolerância à dessecação de sementes de espécies de Eugenia. Pesquisa Agropecuária Brasileira, v.42, p.265-272, 2007. http://dx.doi.org/10.1590/S0100-204X2007000200016 
DELGADO, L.F.; BARBEDO, C.J. Atividade inibidora da germinação em extratos de sementes Eugenia uniflora L. Revista Brasileira de Sementes, v.33, n.3, p.463-471, 2011. http://dx.doi.org/10.1590/S0101-31222011000300009

DELGADO, L.F.; BARBEDO, C.J. Water potential and viability of seeds of Eugenia (Myrtaceae), a tropical tree species, based upon different levels of drying. Brazilian Archives of Biology and Technology, v.55, p.583-590, 2012. http://dx.doi.org/10.1590/S1516-89132012000400014

DELGADO, L.F.; MELlO, J.I.O.; BARBEDO, C.J. Potential for regeneration and propagation from cut seeds of Eugenia (Myrtaceae) tropical tree species. Seed Science and Technology, v.38, p.624-634, 2010. http:// dx.doi.org/10.15258/sst.2010.38.3.10

DEO, P.C.; TYAGI, A.P.; TAYLOR, M.; HARDING, R.; BECKER, D. Factors affecting somatic embryogenesis and transformation in modern plant breeding. The South Pacific Journal of Natural and Applied Sciences, v.28, p.27-40, 2010. http://dx.doi.org/10.1071/SP10002

GURGEL, J.T.A.; SOUBIHE SOBRINHO, J. Poliembrionia em mirtáceas frutíferas. Bragantia, v.11, p.141-163, 1951.

ISTA. International rules for seed testing. Seed Science and Technology, v.13, p.356-513, 2015. http://www.seedtest.org/en/international-rulescontent---1--1083.html

JUSTO, C.F.; ALVARENGA, A.A.; ALVES, E.; GUIMARÃES, R.M.; STRASSBURG, R.S. Efeito da secagem, do armazenamento e da germinação sobre a micromorfologia de sementes de Eugenia pyriformis Camb. Acta Botanica Brasilica, v.21, p.539-551, 2007. http://dx.doi.org/10.1590/S010233062007000300004

KANWAR, K.; JOSEPH, J.; DEEPIKA, R. Comparison of in vitro regeneration pathways in Punica granatum L. Plant Cell, Tissue and Organ Culture, v.100, p.199-207, 2010. http://dx.doi.org/10.1007/s11240-009-9637-4

KARAMI, O.; SAIDI, A. The molecular basis for stress-induced acquisition of somatic embryogenesis. Molecular Biology Reports, v.37, p.2493-2507, 2010. http://dx.doi.org/10.1007/s11033-009-9764-3

KOHAMA, S.; MALUF, A.M.; BILIA, D.A.C.; BARBEDO, C.J. Secagem e armazenamento de sementes de Eugenia brasiliensis Lam. (grumixameira). Revista Brasileira de Sementes, v.28, p.72-78, 2006. http://dx.doi. org/10.1590/S0101-31222006000100010
LANDRUM, L.R.; KAWASAKI, M.L. The genera of Myrtaceae in Brazil: an illustrated synoptic treatment and identification keys. Brittonia, v.49, p.508 536, 1997. http://dx.doi.org/10.2307/2807742

MARCOS-FILHO, J. Fisiologia de sementes de plantas cultivadas. 2.ed. Londrina, ABRATES, 2015. 660p.

PEREIRA, C.E.; VON PINHO, E.V.R.; OLIVEIRA, D.F.; KIKUTI, A.L.P Determinação de inibidores da germinação no espermoderma de sementes de café (Coffea arabica L.). Revista Brasileira de Sementes, v.24, p.306-311, 2002. http://dx.doi.org/10.1590/S0101-31222002000100042

PRATAVIERA, J.S.; LAMARCA, E.V.; TEIXEIRA, C.C.; BARBEDO, C.J. The germination success of the cut seeds of Eugenia pyriformis depends on their size and origin. Journal of Seed Science, v.37, n.1, p.47-54, 2015. http:// www.scielo.br/pdf/jss/v37n1/2317-1537-jss-37-01-00047.pdf

RIZZINI, C.T. Efeito tegumentar na germinação de Eugenia dysenterica DC. (Myrtaceae). Revista Brasileira de Biologia, v.30, p.381-402, 1970.

SALOMÃO, A.N.; ALLEM, A.C. Polyembryony in angiospermous trees of the Brazilian Cerrado and Caatinga vegetation. Acta Botanica Brasilica, v.15, p.369-378, 2001. http://dx.doi.org/10.1590/S0102-33062001000300007

SILVA, C.V.; BILIA, D.A.C.; MALUF, A.M.; BARBEDO, C.J. Fracionamento e germinação de sementes de uvaia (Eugenia pyriformis Cambess. - Myrtaceae). Revista Brasileira de Botânica, v.26, p.213-221, 2003. http://dx.doi.org/10.1590/S0100-84042003000200009

SILVA, C.V.; BILIA, D.A.C.; BARBEDO, C.J. Fracionamento e germinação de sementes de Eugenia. Revista Brasileira de Sementes, v.27, p.86-92, 2005 http://dx.doi.org/10.1590/S0101-31222005000100011

SWAMY, M.K.; SUDIPTA, K.M.; BALASUBRAMANYA, S.;ANURADHA, M. Effect of different carbon sources on in vitro morphogenetic response of patchouli (Pogostemon cablin Benth.). Journal of Phytology, v.2, p.11-17, 2010. http://journal-phytology.com/index.php/phyto/article/view/4377/2167

TEIXEIRA, C.C.; BARBEDO, C.J. The development of seedlings from fragments of monoembryonic seeds as an important survival strategy for Eugenia (Myrtaceae) tree species. Trees, structure and function, v.26, p.10691077, 2012. http://dx.doi.org/10.1007/s00468-011-0648-5. 